\title{
Laryngeal actinomycosis mimicking relapse of laryngeal carcinoma in a 67-year-old man
}

\author{
${ }^{1}$ Service de Maladies Infectieuses et Tropicales, Hospices Civils de Lyon, Lyon, France \\ ${ }^{2}$ Université Claude Bernard Lyon 1, Lyon, France \\ ${ }^{3}$ INSERM U851, Pathogénie Bactérienne et Immunité Innée, Lyon, France \\ ${ }^{4}$ Service d'Oto-Rhino-Laryngologie, Hospices Civils de Lyon, Lyon, France
}

Tristan Ferry, ${ }^{1,2,3}$ Guillaume Buiret, ${ }^{2,4}$ Jean-Christian Pignat, ${ }^{2,4}$ Christian Chidiac 1,2,3

Correspondence to Dr Tristan Ferry, tristan.ferry@univ-lyon1.fr

\section{DESCRIPTION}

A 67-year-old man, a heavy smoker with a history of myocardial infarction, was followed up for a T3N2M0 laryngeal carcinoma. After primary chemotherapy, lateral pharyngo-laryngectomy was performed, followed by radiotherapy. Two-years later, mild dyspnoea at rest appeared and a relapse was suspected, as an ulcerated lesion with oedema was detected during endoscopy (figure 1A). Pathological examination of biopsies revealed cartilage suppurative necrosis with sulphur granules (figure 1C) and filamentous Gram-positive fungal-like pathogen (figure 1D). Actinomyces odontolyticus grew in bacterial cultures. Oral amoxicilline (6g/day) was prescribed. One month later, the laryngeal lesion disappeared (figure 1B). The antimicrobial therapy was prolonged to 3 months. No relapse occurred during the follow-up.
Actinomyces spp. are fastidious organisms that belong to the commensal oral flora. ${ }^{1}$ Cervicofacial actinomycosis is a chronic infectious disease usually associated with neglected dental infections or oro-maxillo-facial trauma, resulting in direct and progressive mucosal invasion of Actinomyces spp. Typically, actinomycosis is associated with large slow-progressive multiple abscess formations with draining sinus tracts. ${ }^{1}$ Laryngeal actinomycosis is poorly described, as $\sim 20$ cases are reported in the literature only. ${ }^{2}{ }^{3}$ It is noteworthy that most of patients, as in our case: (1) had a history of laryngeal carcinoma and radiotherapy and (2) presented with an ulceration mimicking laryngeal cancer relapse, neither with abscess nor sinus tract. $^{2}{ }^{3}$ Pathological analysis is of crucial importance for the diagnosis, as the bacterial cultures could be negative. ${ }^{1}$ Surgery is not required for such limited lesion, as oral
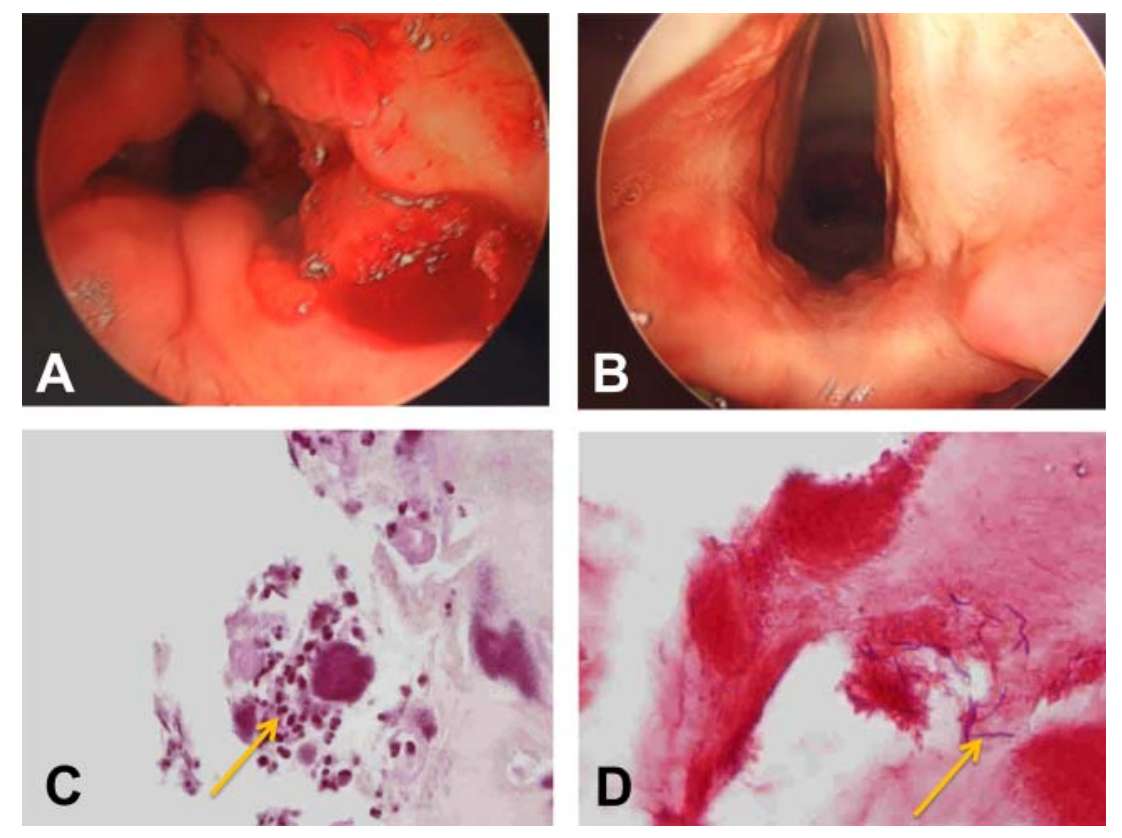

Figure 1 Endoscopy aspect of the larynx before ( $A$; showing a limited ulceration with mucosal oedema) and after one month of amoxicillin therapy (B). Pathological examination of the biopsies revealing cartilage suppurative necrosis with sulfure granules (C, arrow; Hematoxylin Erythrosine Saffron staining, X40) and filamentous Gram-positive fungal-like pathogen (D, arrow; $\times 100)$. 


\section{BMJ Case Reports}

prolonged penicillin or amoxicillin therapy is usually associated with a successful clinical response.

\section{Learning points}

Laryngeal actinomycosis:

- could be observed in patients with past history of laryngeal cancer and radiotherapy,

- may mimic cancer relapse, as the clinical presentation might be limited to a an ulcerated lesion, neither with abscess nor with sinus tract,

- usually respond well to prolonged penicillin or amoxicillin therapy.
Acknowledgements We acknowledge Olivier Chéraud, Chantal Roure and Frédérique Le Breton for their help.

\section{Competing interests None.}

\section{Patient consent Obtained.}

\section{REFERENCES}

1. Wong VK, Turmezei TD, Weston VC. Actinomycosis. BMJ 2011;343:d6099 doi: $10.1136 / \mathrm{bmj} . d 6099$

2. Zitsch RP III, Bothwell M. Actinomycosis: a potential complication of head and neck surgery. Am J Otolaryngol 1999;20:260-2.

3. Batur Caliş A, Ozbal AE, Başak T, et al. Laryngeal actinomycosis accompanying laryngeal carcinoma: report of two cases. Eur Arch Otorhinolaryngol 2006;263:783-5.

This pdf has been created automatically from the final edited text and images.

Copyright 2012 BMJ Publishing Group. All rights reserved. For permission to reuse any of this content visit http://group.bmj.com/group/rights-licensing/permissions.

BMJ Case Report Fellows may re-use this article for personal use and teaching without any further permission.

Please cite this article as follows (you will need to access the article online to obtain the date of publication).

Ferry T, Buiret G, Pignat J-C, Chidiac C. Laryngeal actinomycosis mimicking relapse of laryngeal carcinoma in a 67-year-old man. BMJ Case Reports 2012;10.1136/bcr-2012-007084, Published XXX

Become a Fellow of BMJ Case Reports today and you can:

- Submit as many cases as you like

- Enjoy fast sympathetic peer review and rapid publication of accepted articles

- Access all the published articles

- Re-use any of the published material for personal use and teaching without further permission

For information on Institutional Fellowships contact consortiasales@bmjgroup.com

Visit casereports.bmj.com for more articles like this and to become a Fellow 